\title{
Understanding university students' smoking behaviors towards tobacco-free campus policy
}

\author{
Mehmet KARADAĞ ${ }^{1}$ (ID) \\ Özge AYDIN \\ GÜÇLÜ ${ }^{1}(I D)$ \\ Aslı GÖREK \\ DILEKTAŞLI $^{1}$ (ID) \\ Funda COȘKUN ${ }^{1}(I D)$ \\ Esra UZASLAN ${ }^{1}($ ID)
}

\author{
${ }^{1}$ Department of Chest Diseases, Uludağ University Faculty of Medicine, \\ Bursa, Turkey \\ ${ }^{1}$ Uludağ Üniversitesi Tıp Fakültesi, Gögüs Hastalıkları Anabilim Dalı, \\ Bursa, Türkiye
}

Cite this article as: Karadağ $M$, Aydın Güçlü Ö, Görek Dilektaşı A, Coşkun F, Uzaslan E. Understanding university students' smoking behaviors towards tobacco-free campus policy. Tuberk Toraks 2021;69(1):49-58.

Yazışma Adresi (Address for Correspondence)

\section{Dr. Özge AYDIN GÜÇLÜ}

Uludağ Üniversitesi Tıp Fakültesi,

Göğüs Hastalıkları Anabilim Dalı,

BURSA - TÜRKIYE

e-mail: drozgeaydinguclu@gmail.com

CCopyright 2021 by Tuberculosis and Thorax.

Available on-line at www.tuberktoraks.org.com

\begin{abstract}
Understanding university students' smoking behaviors towards tobacco-free campus policy

Introduction: Tobacco-free college campuses refer to colleges and universities that have implemented policies prohibiting the use of tobacco products at all indoor and outdoor campus locations. We aimed to evaluate university students' smoking behaviors and their attitudes towards "Tobacco-Free Campus Policy".
\end{abstract}

Materials and Methods: A total of 10,383 university students were included in this cross-sectional study. The questionnaire was sent via web-based student information system. Demographical variables, the frequency of tobacco use, the addiction levels of the smoker students, and their perspective on the Tobacco-Free Campus Policy were evaluated.

Results: The study population consisted of 5461 (52.6\%) males and their mean age was $22.1 \pm 3.9$ years. Among the students, 3992 (38.4\%) were current smokers and the age of first smoking was $16.5 \pm 2.78$ years. According to FTND scores, $15.1 \%$ of participants have high dependence, and $7.5 \%$ of them have very high dependence. There was a significant difference among participants who finds unacceptable "Tobacco-Free Campus Policy" in terms of gender (70.7\% males vs. $29.3 \%$ females, $p<0.001)$ and smoking habit (7\% never smoker, $4.1 \%$ ex-smoker, $88.9 \%$ current smoker, $p<0.001$ ).

Conclusion: The Tobacco-Free Campus Policy is important to fight against the tobacco industry in order to protect the right to health of all tobacco users and those who do not use it and should be considered as a goal to be achieved in order to live in a healthy environment.

Key words: Tobacco; tobacco-free campus policy; university students; addiction 
Öz

Üniversite öğrencilerinin sigara kullanma durumları ve tütünsüz kampüs politikasına yönelik tutumlarının değerlendirilmesi

Giriş: Üniversitelerde tütün kontrolü çalışmalarını sistematik ve sürekli bir biçimde sürdürme gereksinimi bulunmaktadır. "Tütünsüz Kampüs" yaklaşımı bu amaçla dünyada benimsenmiş uygulamalar bütünüdür.

Materyal ve Metod: Çalışmamızda üniversite öğrencilerinin demografik özellikleri, tütün kullanım sıklıkları, sigara içen öğrencilerin bağımlıık düzeyleri ile Tütünsüz Kampüs Projesi'ne bakış açılarının değerlendirilmesi amaçlandı. Google Dokümanlar aracılığı ile hazırlanmış olan anket üniversitenin öğrenci bilgi sistemi üzerinden tüm üniversite öğrencilerine gönderildi. Hedeflenen 15,000 öğrencinin 10,383'ü $(\% 69,22)$ anketi başarı ile tamamladı.

Bulgular: Katılımcıların 4922'si (\% 47,4) kız öğrenci, yaş ortalaması 22,1 1 3,95 idi. Katılımcıların sigara içmeye başlama yaşı ortalama 16,5 \pm 2,78 olup \%51,1'i hiç sigara kullanmamış, \%10.4'ü kullanıp bırakmış, \%38,4'ü halen kullanmakta idi. Sigaraya başlama nedenleri en sık arkadaş ortamı $(\% 44,6)$, merak $(\% 38,8)$ ve stres $(\% 37,2)$ iken sigarayı bırakma nedenlerinin en sık sağlıklı olmak için $(65,3 \%)$, sigaranın kötü kokusu $(\% 34,5)$ ve çekici gelmemesi $(\% 32,9)$ nedeniyle olduğu tespit edildi. Sigara içen katılımcıların \%41'i sigarayı bırakıp tekrar başlamıştı. Sigaraya tekrar başlamaları en sık stres (\%52,9), sigara içmenin keyifli olması (\%34,4) ve

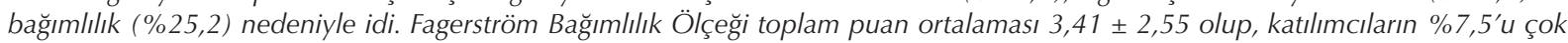
ileri derecede, \%15,5'i ileri derecede, \%10,2'si orta derecede, \%25,6'sı hafif düzeyde, \%41,2'si çok hafif düzeyde bağımlı idi. Katılımcıların \%50'si "Tütünsüz Kampüs" projesini desteklemekte idi, \%13,9'u projenin uygun olabileceğini, \%22,6'sı gereksiz bir kısıtlama olacă̆ını, \% 13,6'sı kabul edilemez olduğunu bildirdi.

Sonuç: Tütünsüz Kampüs Projesi, tütün kullanan ve kullanmayan herkesin sağılk hakkının korunması için tütün endüstrisi ile mücadelede önemli bir uygulamadır ve sağlıklı bir çevrede yaşayabilmek için de ulaşılması gereken bir hedef olarak kabul edilmelidir.

Anahtar kelimeler: Tütün; tütünsüz kampüs projesi; üniversite öğrencileri; bağımlılık

\section{INTRODUCTION}

Tobacco use is the most important preventable disease in Turkey and the world and is located on the first place among the causes of death (1). Adolescence and youth are risky periods in terms of the use of any tobacco product. An important part of this age group starts using tobacco in their university life. Therefore, preventing the use of tobacco in these special periods can be a rational solution to reduce the frequency of tobacco use by individuals and communities. The World Health Organization (WHO) Framework Convention on Tobacco Control places an important emphasis on the prevention of tobacco use by young people. In our country, the prevention of tobacco use by young people was considered as a topic in the Tobacco Control Strategy Document and Action Plan (2).

Tobacco-free college campuses refer to colleges and universities that have implemented policies prohibiting the use of tobacco products at all indoor and outdoor campus locations. It is important to raise awareness about the reasons why the campus is going tobacco-free so the programs also include a large educational component. Program work should also include cessation services or services that help interested tobacco users to quit. While the actual tobacco-free campus policy is arguably the most important piece of this work, education, and cessation support policy efforts and work to further change the tobacco norms on campus. A tobacco-free policy limits or eliminates the use of any tobacco product, including, but not limited to cigarettes, cigars, cigarillos, mini-cigars, hookah, spit tobacco, snus, and other smokeless products. Also it often includes innovations in smoke or tobacco products, such as electronic cigarettes. The primary concern of a tobacco-free policy is the overall health and ethical behavior of the student body. A comprehensive tobacco-free program may also address tobacco sales, marketing, sponsorship, and investments.

We aimed to evaluate university students' smoking behaviors and their attitudes towards "Tobacco-Free Campus Policy".

\section{MATERIALS and METHODS}

A cross-sectional survey was conducted upon the approval of the Clinical Research Ethics Board of the Medical School of Bursa Uludağ University (approval number: 2019-11/19). University students from fifteen faculties, fifteen vocational schools and three colleges who agreed to take part in this study were enrolled between June 2019 and September 2019 and were administered an online questionnaire. The questionnaire was prepared using the Google Docs website and was sent to 12.000 university students 
via web-based student information system. Effective responses were obtained from 10.383 individuals (effective response rate, $86.52 \%$ ), who constituted the study sample. The university students who agreed to participate in the study provided answers to the questionnaire and other relevant information individually and anonymously. The present study was conducted with adherence to ethical values, and in line with the Helsinki Declaration, with voluntary participation.

The questionnaire used for this study requested data on demographical variables (age, gender, marital status), general health-related variables (tobacco use) the frequency of tobacco use, the addiction levels of the smoker students, and their perspective on the Tobacco-Free Campus Policy. They were also asked if they were current, ever, or never smokers. Someone who has smoked greater than 100 cigarettes in their lifetime and has smoked in the last 28 days defined as "current smoker" and someone who has smoked greater than 100 cigarettes in their lifetime but has not smoked in the last 28 days defined as "ex-smok$e^{\prime \prime}$ ". An "ever-smoker" is defined as someone who had smoked at least 100 cigarettes in their lifetime, while a "never-smoker" is defined as someone who smoked less than 100 cigarettes and does not currently smoke.

\section{The measure of Nicotine Dependence}

Fagerström Test for Nicotine Dependence (FTND): The FTND is a standard instrument for assessing the intensity of physical addiction to nicotine. The test was designed to provide an ordinal measure of nicotine dependence related to cigarette smoking. It contains six items that evaluate the quantity of cigarette consumption, the compulsion to use, and dependence.

In scoring the Fagerstrom Test for Nicotine Dependence, yes/no items are scored from 0 to 1 and multiple-choice items are scored from 0 to 3 . The items are summed to yield a total score of 0-10. The higher the total Fagerström score, the more intense is the patient's physical dependence on nicotine. There is no standard cutoff for the presence or absence of nicotine dependence; one suggested scoring system is: $1-2=$ very low dependence; $3-4=$ low dependence; $5=$ medium dependence; $6-7=$ high dependence; $8-10=$ very high dependence.

\section{Statistical Analysis}

Shapiro-Wilk test was used to evaluate the normality of variable distribution. Continuous variables were shown as mean \pm standard deviation and median [minimum-maximum] values. Categorical variables were shown as $\mathrm{n}(\%)$. According to the normality test result, independent samples t-test was used for between group comparisons. Categorical variables were compared by Chi-square test. SPSS (IBM Corp. Released 2012. IBM SPSS Statistics for Windows, Version 21.0. Armonk, NY: IBM Corp.) software was used for statistical analysis, with $\mathrm{p}<0.05$ taken as statistically significant.

\section{RESULTS}

The study population consisted of 5461 (52.6\%) males and their mean age was $22.1 \pm 3.9$ years. Table 1 shows the characteristics of all 10.383 university students. Most of the students $(40.3 \%)$ were staying with their families at home. The major educational level of the students' fathers was university and their mothers' educational level was primary school $(25.6 \%$ and $33.8 \%$, respectively). Illiterate fathers and mothers were $1 \%$ and $5.1 \%$. Family income was less than 2000 Turkish Lira (TL) ( €300/\$325/£250) per month for $23.2 \%$ of the students. Among the 10.383 students, $3992(38.4 \%)$ were current smokers, 1084 (10.4\%) were ex-smokers and 5307 (51.1\%) were non-smokers. The questionnaire showed that $49.1 \%$ of males and $26.7 \%$ of females were current smokers, $11.8 \%$ of males and $8.9 \%$ of females were ex-smokers, and $39.1 \%$ of males and $64.4 \%$ of females were nonsmokers ( $p<0.001$ for each). $8 \%$ of students had a comorbid disease. The most common comorbid diseases among participants were asthma $(n=216)$, depression $(n=96)$, diabetes mellitus $(n=$ $44)$, cardiovascular disease $(n=43)$, and hypertension $(n=26) .53 .8 \%$ of the participants with hypertension, $41.8 \%$ of the participants with cardiovascular disease, $61.4 \%$ of the participants with diabetes mellitus, $52.1 \%$ of participants with depression, and $27.8 \%$ of the participants with asthma were current-smokers. The age of first smoking was $16.5 \pm$ 2.78 years. According to FTND scores, $41.2 \%$ of participants have very low dependence, $25.6 \%$ of them have low dependence, $10.2 \%$ of them have medium dependence, $15.1 \%$ of them have high dependence, and $7.5 \%$ of them have very high dependence (Table 2$)$. Their mean FTND $( \pm$ SD) total 


\section{Table 1. Characteristics of participants}

$\mathrm{n}=\mathbf{1 0 . 3 8 3}$

Age (year)

$22.1+3.95$

Gender (Female/Male)

$4922(47.4 \%) / 5461(52.6 \%)$

Marital status

Single

$9693(93.4 \%)$

Married

$483(4.7 \%)$

Divorced

$57(0.5 \%)$

Resides

With family at home

$4183(40.3 \%)$

With friends at home

$2061(19.8 \%)$

Single at home

$1066(10.3 \%)$

In a special dormitory

$1362(13.1 \%)$

In university dormitory

$1711(16.5 \%)$

Mother's level of education

Illiterate

$534(5.1 \%)$

Literate

$360(3.5 \%)$

Primary

$3508(33.8 \%)$

Secondary

$1704(16.4 \%)$

High school

2431(23.4\%)

University

$1541(14.8 \%)$

Father's level of education

Illiterate

$106(1 \%)$

Literate

$218(2.1 \%)$

Primary

$2479(23.9 \%)$

Secondary

$1743(16.8 \%)$

High school

$2868(25.6 \%)$

University

$2660(27.8 \%)$

Comorbidity (yes/no)

$828(8 \%) / 9555(92 \%)$

Income Level, Turkish lira

$<2000$

$2412(23.2 \%)$

2000-5000

$5082(48.9 \%)$

5000-10000

$2146(20.7 \%)$

$>10000$

$743(7.2 \%)$

Smoking status

Current smoker

$3992(38.4 \%)$

Ex-smoker

$1084(10.4 \%)$

Non-smoker

$5307(51.1 \%)$

Cigarettes (pkg/year)

$$
5(1-78)
$$

Age at smoking onset (year)

$16.5 \pm 2.78$

Data are presented as mean \pm st.deviation, median (min.: max.) and $n(\%)$. 
Table 2. Fagerstrom test for nicotine dependence scores of the participants

\begin{tabular}{|lcc|}
\hline Addiction levels & N & \% \\
\hline Very Low Dependence (0-2) & 1761 & 41.2 \\
Low Dependence (3-4) & 1096 & 25.6 \\
Medium Dependence (5) & 438 & 10.2 \\
High Dependence (6-7) & 663 & 15.5 \\
Very High Dependence (8-10) & 319 & 7.5 \\
\hline FTND Total Score $3.41 \pm 2.55$ & & \\
\hline
\end{tabular}

score was $3.41 \pm 2.55$. There was a significant difference between the age of starting smoking and FTND total scores in terms of gender. The age of first smoking mean value was $17.22 \pm 2.60$ years for females and $16.25 \pm 2.81$ years for males $(p<0.001)$. The total score of FTND was $2.90 \pm 2.51$ for females and $3.67 \pm 2.54$ for males $(\mathrm{p}<0.001)$.

Participants' reasons to start smoking, smoking cessation, and to re-start smoking were shown in Figure 1, 2,
3. While the reasons for starting smoking are the most frequent friend environment $(44.6 \%)$, curiosity $(38.8 \%)$ and stress $(37.2 \%)$, the most common reasons for quitting smoking are to be healthy $(65.3 \%)$, bad smell of cigarette $(34.5 \%)$ and non-attractive of smoking (\%32.9) was found. $41 \%$ of the participants who quit smoking have re-started smoking. Restarting tobacco smoking was most frequently due to stress (52.9\%), plesant smoking (34.4\%), and addiction (25.2\%).

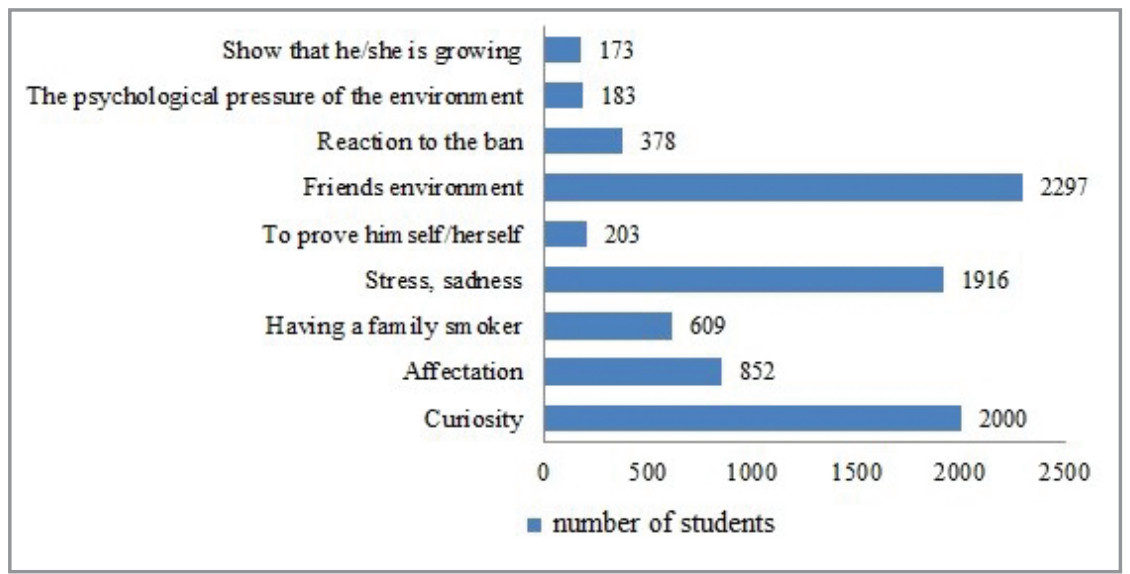

Figure 1. Participants' reasons to start smoking.

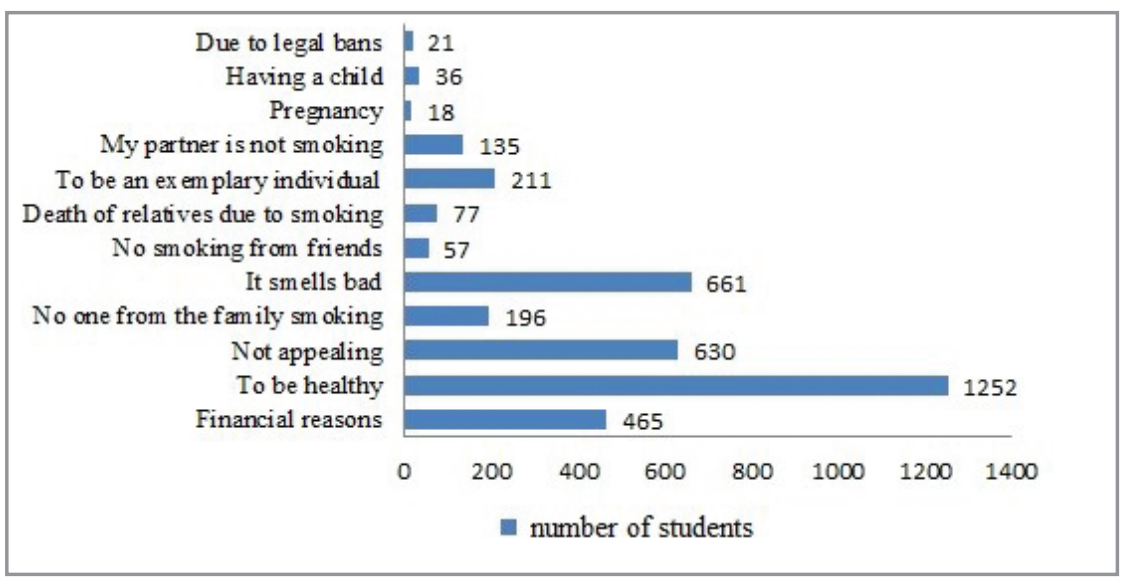

Figure 2. Participants' smoking cessation reasons. 


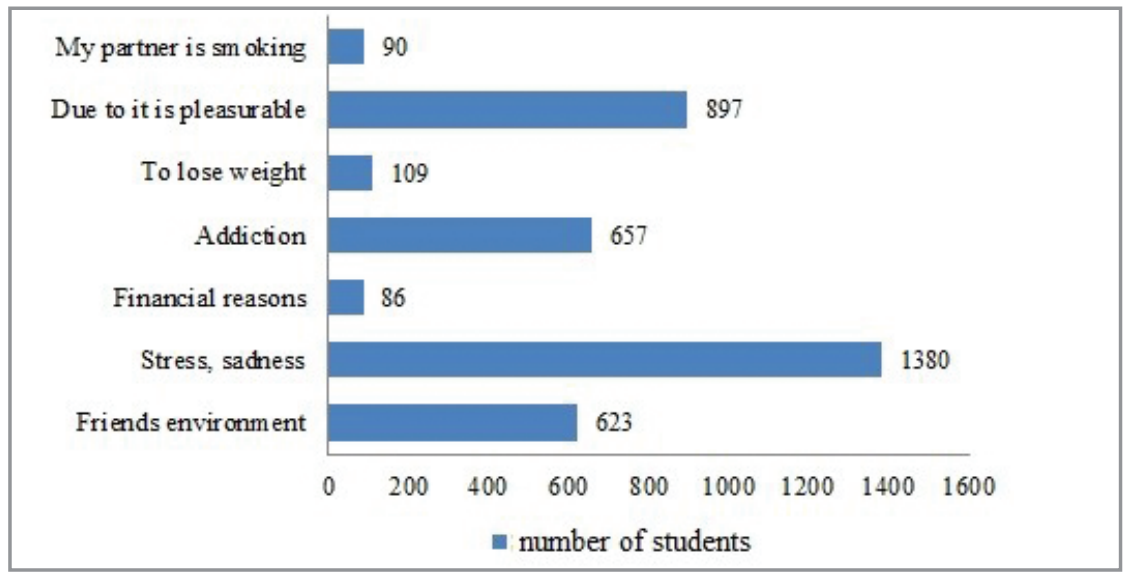

Figure 3. Participants' reasons to start smoking again.

The associations of smoking status with sociodemographic features are summarized in Table 3. Table 4 shows the attitudes of all the university students toward tobacco bans and "Tobacco-Free Campus Policy". There was a significant difference among participants who finds unacceptable "Tobacco-Free Campus Policy" in terms of gender $(70.7 \%$ males vs $29.3 \%$ females, $p<0.001)$ and smoking habit $(7 \%$ never smoker, $4.1 \%$ ex-smoker, $88.9 \%$ current smoker, $\mathrm{p}<0.001$ ). There was also a significant difference among participants who finds unacceptable "Tobacco-Free Campus Policy" in terms of income levels $(p<0.001)$ (Table 5).

\section{DISCUSSION}

The tobacco-free campus policies have been created to improve health standards, provide more enjoyable campus conditions, and reduce tobacco's adverse environmental effects. In this study, we investigated the university students' smoking behaviors and their attitudes towards "Tobacco-Free Campus Policy". Approximately $50 \%$ of the students who participated in the survey indicated that they supported the policy. There was a significant difference among participants who find unacceptable "Tobacco-Free Campus Policy" regarding gender and smoking habits. However, consistent with previous studies, women participants were more likely to support the policy than men $(3,4)$.

Smoking in Turkey is banned in government offices, workplaces, bars, restaurants, cafés, shopping malls, schools, hospitals, and all forms of public transport, including trains, taxis, and ferries. Turkey's smoking ban includes provisions for violators, where anyone caught smoking in a designated smoke-free area faces a fine of $69 \mathrm{TL}(\sim € 15 / \$ 18 / £ 13)$ and bar owners who fail to enforce the ban could be fined from 560 TL for a first offence up to 5.600 TL. Smoking was first banned in 1997 in public buildings with more than four workers, as well as airplanes and public buses. On 3 January 2008, Turkey passed a smoking ban for all indoor spaces including bars, cafés, and restaurants. It also bans smoking in sports stadia and the gardens of mosques and hospitals. The smoking ban came into force on 19 May 2008; however, bars, restaurants, and cafes were exempted until mid-July 2009. On 19 July 2009, Turkey extended the indoor public smoking ban to include bars, restaurants, village coffee houses, and hookah bars. The ban also forbids smoking advertising and the depiction of people smoking on television. Many foreign programs or films that have scenes with characters smoking will usually have the cigarettes blurred out. In December 2018 the law was changed to require plain packaging of all tobacco products. Health warnings messages and images must cover both sides of packages and at least $85 \%$ of the packaging.

Smoking bans have also been enforced in school settings showing notable success. One study found that smoking bans implemented at schools with high enforcement were associated with a lower prevalence of smoking and with preventing the transition into regular smoking among high school students (5-7).

Smoke-free college campus policies have been associated with a drop in student smoking rates. Secondhand smoke (SHS) exposure is also a major public health threat. Exposure to any amount of SHS can lead to negative health outcomes (8). Short-term exposure to SHS places an individual at approxi- 
Table 3. Association of smoking status with sociodemographic features

\begin{tabular}{|c|c|c|c|}
\hline & Ever Smoker $(n=5076)$ & Never Smoker $(n=5307)$ & $\mathbf{p}$ \\
\hline Age (year) & $22.35 \pm 3.98$ & $22.95 \pm 3.90$ & $<0.001$ \\
\hline \multicolumn{4}{|l|}{ Gender } \\
\hline Female & $2137(40.3 \%)$ & $3170(59.7 \%)$ & \multirow[t]{2}{*}{$<0.001$} \\
\hline Male & $3324(65.5 \%)$ & $1752(34.5 \%)$ & \\
\hline \multicolumn{4}{|l|}{ Marital status } \\
\hline Single & $4756(93.7 \%)$ & $4937(93 \%)$ & \multirow{3}{*}{$<0.001$} \\
\hline Married & $211(4.2 \%)$ & $272(5.1 \%)$ & \\
\hline Divorced & $41(0.8 \%)$ & $16(0.3 \%)$ & \\
\hline \multicolumn{4}{|l|}{ Resides } \\
\hline With family at home & $1909(37.6 \%)$ & $2274(42.8 \%)$ & \multirow{5}{*}{$<0.001$} \\
\hline With friends at home & $1285(25.3 \%)$ & $776(14.6 \%)$ & \\
\hline Single at home & $738(14.5 \%)$ & $328(6.2 \%)$ & \\
\hline In a special dormitory & $515(10.1 \%)$ & $847(16 \%)$ & \\
\hline In university dormitory & $629(12.4 \%)$ & $1082(20.4 \%)$ & \\
\hline \multicolumn{4}{|l|}{ Mother's level of education } \\
\hline Illiterate & $198(3.9 \%)$ & $336(6.3 \%)$ & \\
\hline Literate & $147(2.9 \%)$ & $213(4 \%)$ & \\
\hline Primary & $1559(30.7 \%)$ & $1949(36.7 \%)$ & $<0.001$ \\
\hline Secondary & $883(17.4 \%)$ & $821(15.5 \%)$ & \\
\hline High school & $1318(26 \%)$ & $1113(21 \%)$ & \\
\hline University & $862(17 \%)$ & $679(12.8 \%)$ & \\
\hline \multicolumn{4}{|l|}{ Father's level of education } \\
\hline Illiterate & $41(0.8 \%)$ & $65(1.2 \%)$ & \\
\hline Literate & $87(1.7 \%)$ & $131(2.5 \%)$ & \\
\hline Primary & $1067(21 \%)$ & $1412(26.6 \%)$ & $<0.001$ \\
\hline Secondary & $834(16.4 \%)$ & $909(17.1 \%)$ & \\
\hline High school & $1532(30.2 \%)$ & $1336(25.2 \%)$ & \\
\hline University & $1255(23.6 \%)$ & $1405(27.7 \%)$ & \\
\hline Comorbidity (yes) & $408(8 \%)$ & $420(7.9 \%)$ & 0.828 \\
\hline \multicolumn{4}{|l|}{ Income Level, Turkish Lira } \\
\hline$<2000$ & $928(18.3 \%)$ & $1484(28 \%)$ & \\
\hline $2000-5000$ & $2415(47.6 \%)$ & $2667(50.3 \%)$ & $<0.001$ \\
\hline 5000-10000 & $1257(24.8 \%)$ & $889(16.8 \%)$ & \\
\hline$>10000$ & $476(9.4 \%)$ & $267(5 \%)$ & \\
\hline
\end{tabular}

mately $80 \%$ to $90 \%$ of the cardiovascular risk of firsthand smoking (9). Secondhand smoke claims 50.000 lives annually and is the fourth leading behavior-related cause of death (10). Although the risks of indoor SHS exposure are well documented, the science of outdoor tobacco smoke (OTS) expo- sure is an emerging field. The risk of OTS exposure is dependent on multiple factors, such as wind speed and weather conditions (11). However, OTS can pose a risk similar or equal to that of indoor exposure. In an outdoor setting, secondhand smoke can cause nausea, dizziness, headache, and respiratory irrita- 
Table 4. Participants' perspectives on smoking bans and the "Tobacco-Free Campus Policy"

\begin{tabular}{lc} 
Question & $\mathbf{n}(\%)$ \\
\hline Warnings on cigarette packs cause me to smoke less. (Yes) & $1374(13.2 \%)$ \\
The increase in cigarette prices causes me to smoke less. (Yes) & $3327(32 \%)$ \\
Prohibitions in cigarette advertisements cause me to smoke less. (Yes) & $1830(17.6 \%)$ \\
Smoking ban in confined spaces causes less smoking. (Yes) & $4182(40.3 \%)$ \\
Prohibition of selling tobacco products in places where health, education and training, culture and sports & $3637(35 \%)$ \\
services are provided causes less smoking. (Yes) & $1786(17.2 \%)$ \\
Brand-specific colors, shapes and the brand's emblem on cigarette packs cause me to smoke more. (Yes) & $5120(49.3 \%)$ \\
Does your university have a policy that prohibits smoking in faculty buildings and health clinics? (Yes) & \\
What do you think about the "Tobacco-Free Campus Policy", which includes not using tobacco in indoor and & \\
outdoor areas within the university campus, not selling tobacco in the campus, and providing assistance to those & \\
who want to quit smoking? & $5185(49.9 \%)$ \\
I definitely support & $1438(13.8 \%)$ \\
It could be & $2347(22.6 \%)$ \\
It would be an unnecessary restriction & $1410(13.6 \%)$ \\
Finds unacceptable, opposes &
\end{tabular}

tion in bystanders within 4 feet of the smoker, and is noticeable 23 feet away. Smoke and tobacco-free policies are the optimal public health strategy to reduce SHS and OTS exposure and prevent adverse health outcomes. These policies promote a healthy environment that encourages cessation, as well as reduced exposure to OTS. Having a tobacco-free campus protects students, faculty, staff, and visitors from a complex mixture of gases and particles with at least 250 toxic chemicals (12). No level of secondhand smoke is considered safe because there are at least 50 known toxic chemicals in secondhand smoke that can cause cancer. Providing a tobacco-free policy ensures the protection of the environment, bystanders, and users of tobacco.

In the general population of the study, 38.4\% of participants were current smokers, $10.4 \%$ ex-smokers, and $51.1 \%$ nonsmokers. $49.1 \%$ of males and $26.7 \%$ of females were current smokers. In Turkey, $31.6 \%$ of the population over the age of 15 use tobacco. This rate is $44.1 \%$ for men and $19.2 \%$ for women (13). According to the data of the World Health Organization, there are 367 million people in the world who are trying to quit smoking and have this intention. In Turkey, $32.8 \%$ of tobacco users to quit tobacco are being planned next month in quitting in only $7.2 \%$ of them. Smoking prevalence in universities in Turkey varies between 20 and $48 \%$ (14). Studies show that more than $80 \%$ of smokers started smoking before the age of 18 and individuals who started smoking at an early age became regular smokers during their university years $(15,16)$. The age of first smoking was $16.5 \pm$ 2.78 years in our study. According to FTND scores, $41.2 \%$ of participants have very low dependence, $25.6 \%$ of them have low dependence, $10.2 \%$ of them have medium dependence, $15.1 \%$ of them have high dependence, and $7.5 \%$ of them have very high dependence. It was found in our study that male students had higher FTND scores than female students and started smoking earlier. A study performed in Thailand showed no difference in nicotine dependence between male and female smokers (17).

In this study, there was a statistically significant difference between ever-smokers and never-smokers in terms of age, gender, marital status, mothers' and fathers' level of education, income levels of students. The present study found that the smoking rate was higher in single participants compared to married and divorced people. In our study, $65.5 \%$ of males and $40.3 \%$ of females were ever-smokers. In many countries, women's smoking can be restricted by social pressure applied from both inside and outside of the family due to restrictions through social and religious norms $(18,19)$.

Starting smoking is a result of a complex interaction of social, environmental, psychological, and biological factors (20). Previous studies in our country eval- 
Table 5. Factors affecting participants' perspectives on the "Tobacco-Free Campus Policy"

\begin{tabular}{|c|c|c|c|c|c|}
\hline \multicolumn{6}{|c|}{ Participants' perspectives on the "Tobacco-Free Campus Policy" } \\
\hline & $\begin{array}{l}\text { Definitely supports } \\
\qquad(n=5185)\end{array}$ & $\begin{array}{l}\text { It could be } \\
(n=1438)\end{array}$ & $\begin{array}{l}\text { Finds it unnecessary } \\
\text { restriction } \\
(n=2347)\end{array}$ & $\begin{array}{l}\text { Finds unacceptable } \\
\qquad(n=1410)\end{array}$ & $\mathbf{p}$ \\
\hline \multicolumn{6}{|l|}{ Gender } \\
\hline Male & $2337(45.1 \%)$ & $712(49.5 \%)$ & $1412(60.2 \%)$ & $997(70.7 \%)$ & $<0.001$ \\
\hline Female & $2848(54.9 \%)$ & $726(50.5 \%)$ & $935(39.8 \%)$ & $413(29.3 \%)$ & \\
\hline \multicolumn{6}{|c|}{ Income Level, Turkish lira } \\
\hline$<2000$ & $1388(26.8 \%)$ & $391(27.2 \%)$ & $413(17.6 \%)$ & $219(15.5 \%)$ & \\
\hline $2000-5000$ & $2581(49.8 \%)$ & $724(50.3 \%)$ & $1175(50.1 \%)$ & $600(42.6)$ & $<0.001$ \\
\hline $5000-10000$ & $931(18 \%)$ & $252(17.5 \%)$ & $560(23.9 \%)$ & $403(28.6 \%)$ & \\
\hline$>10000$ & $285(5.5 \%)$ & $71(4.9 \%)$ & $199(8.5 \%)$ & $188(13.3 \%)$ & \\
\hline \multicolumn{6}{|c|}{ Mother's level of education } \\
\hline Illiterate & $307(5.9 \%)$ & $88(6.1 \%)$ & $95(4 \%)$ & $44(3.1 \%)$ & \\
\hline Literate & $213(4.1 \%)$ & $54(3.8 \%)$ & $59(2.5 \%)$ & $33(2.3 \%)$ & \\
\hline Primary & $1905(36.7 \%)$ & $530(36.9 \%)$ & $726(30.9 \%)$ & $346(24.5 \%)$ & $<0.001$ \\
\hline Secondary & $812(15.7 \%)$ & $232(16.1 \%)$ & $420(17.9 \%)$ & $239(17 \%)$ & \\
\hline High school & $1088(21 \%)$ & $319(22.2 \%)$ & $632(26.9 \%)$ & $392(27.8 \%)$ & \\
\hline University & $698(13.5 \%)$ & $159(11.1 \%)$ & $364(15.5 \%)$ & $320(22.7 \%)$ & \\
\hline \multicolumn{6}{|c|}{ Father's level of education } \\
\hline Illiterate & $54(1 \%)$ & $25(1.7 \%)$ & $12(0.5 \%)$ & $15(1.1 \%)$ & \\
\hline Literate & $123(2.4 \%)$ & $31(2.2 \%)$ & $48(2 \%)$ & $16(1.1 \%)$ & \\
\hline Primary & $1372(26.5 \%)$ & $392(27.3 \%)$ & $476(20.3 \%)$ & $239(17 \%)$ & $<0.001$ \\
\hline Secondary & $890(17.2 \%)$ & $251(17.5 \%)$ & $404(17.2 \%)$ & $196(13.9 \%)$ & \\
\hline High school & $1327(25.6 \%)$ & $365(25.4 \%)$ & $747(31.8 \%)$ & $429(30 \%)$ & \\
\hline University & $1258(17.2 \%)$ & $316(22 \%)$ & $606(25.8 \%)$ & $479(34 \%)$ & \\
\hline
\end{tabular}

uating smoking habits in various age groups revealed that the main reasons for starting to smoke are friends, curiosity, adaptation to the surrounding, feeling good, habit, and smokers in the family $(21,22)$. In our study, the reasons for starting smoking are the most frequent friend environment $(44.6 \%)$, curiosity $(38.8 \%)$ and stress $(37.2 \%)$, the most common reasons for quitting smoking are to be healthy $(65.3 \%)$, bad smell of cigarette (34.5\%) and non-attractive of smoking $(32.9 \%)$ was found. $41 \%$ of the participants who quit smoking have re-started smoking. Restarting tobacco smoking was most frequently due to stress $(52.9 \%)$, pleasant smoking $(34.4 \%)$, and addiction $(25.2 \%)$. The subjects included in our study had started smoking because they were most affected by their friends. Our results were consistent with those found in our country and other countries $(22,23)$.
Our study has certain limitations. Since our study has made use of subjective tests, it might have led to response bias.

Engaging students in the tobacco-free movement embodies a fundamental procedure of self-determination, as the policy uniquely affects this population. Student participation may be difficult to obtain if an apathetic or libertarian social environment exists on campus. Fostering support and momentum involves facilitating collaboration among several student organizations. In order to increase student involvement, relevant student organizations should be solicited for support, along with student-centered activities to raise awareness such as collecting signatures, holding students' debates, and conducting opinion polls.

The Tobacco-Free Campus Policy is important to fight against the tobacco industry in order to protect the 
right to health of all tobacco users and those who do not use it and should be considered as a goal to be achieved in order to live in a healthy environment.

Ethical Committee Approval: This study was obtained from Uludağ University Clinical Research Ethical Committee (Date: 26.06.2019, Decision No: 201911/19).

\section{CONFLICT of INTEREST}

The authors of this meta-analysis declare that they have no conflict of interest.

\section{AUTHORSHIP CONTRIBUTIONS}

Concept/Design: MK, OAG, AGD, FC, EU

Analysis/Interpretation: OAG, AGD

Data Acqusition: MK, OAG, AGD, FC, EU

Writing: MK, OAG, AGD

Clinical Revision: FC, EU

Final Approval: MK, OAG, AGD, FC, EU

\section{REFERENCES}

1. Bilir N, Çakır B, Dağlı E, Ergüder T, Önder Z. Tobacco control in Turkey. Who Europe 2009; 43-5.

2. Halk Sağlığı Genel Müdürlüğü. Tütün Eylem Planı. Available from: https://hsgm.saglik.gov.tr/depo/birimler/ tutunmucadelebagimlilikdb/haberler/tutun_eylem_plani/ Tutun_Kontrolu_Strateji_Belgesi_ve_Eylem_Plani.pdf.

3. Rayens MK, Hahn EJ, Langley RE, Zhang M. Public support for smoke-free laws in rural communities. Am I Prev Med 2008; 34(6): 519-22.

4. Rayens MK, Hahn EJ, Langley RE, Hedgecock S, Butler KM, Greathouse-Maggio L. Public opinion and smoke-free laws. Policy Polit Nurs Pract 2007; 8(4): 262-70.

5. Wakefield MA, Chaloupka FI, Kaufman NI, Orleans CT, Barker DC, Ruel EE. Effect of restrictions on smoking at home, at school, and in public places on teenage smoking: cross sectional study. BMJ 2000; 321(7257): 333-7.

6. Seo D-C, Macy JT, Torabi MR, Middlestadt SE. The effect of a smoke-free campus policy on college students' smoking behaviors and attitudes. Prev Med 2011; 53(4-5): 347-52.

7. Cooper TV, Cabriales JA, Hernandez N, Law J. A baseline assessment of attitudes toward tobacco free campus policies in a US/México border university. Addict Behav 2016; 60: 223-7.

8. Holliday JC, Moore GF, Moore LA. Changes in child exposure to secondhand smoke after implementation of smoke-free legislation in Wales: a repeated cross-sectional study. BMC Public Health 2009; 9(1): 430.

9. Barnoya J, Glantz SA. Cardiovascular effects of secondhand smoke: nearly as large as smoking. Circulation 2005; 111(20): 2684-98.
10. Sureda X, Fernández E, Martínez-Sánchez IM, Fu M, López MJ, Martínez C, et al. Secondhand smoke in outdoor settings: smokers' consumption, non-smokers' perceptions, and attitudes towards smoke-free legislation in Spain. BMJ Open 2015; 5(4): 007554.

11. Klepeis NE, Ott WR, Switzer P. Real-time measurement of outdoor tobacco smoke particles. II Air Waste Manag Assoc 2007; 57(5): 522-34.

12. Glassman TJ, Reindl DM, Whewell AT. Strategies for implementing a tobacco-free campus policy. I Am Coll Health 2011; 59(8): 764-8.

13. Öntaş E, Aslan D. Küresel Yetişkin Tütün Araştırmasi Türkiye - HÜTF Halk Sağlı̆̆ı AD Toplum için Bilgilendirme Serisi (2018-2019;63). Available from: http://www.halksagligi.hacettepe.edu.tr/duyurular/halkayonelik/ kyta2016.pdf

14. Arslan YT, Pirinççi S, Okyay P, Döger FK. Tobacco use and related factors among Adnan Menderes University Faculty of Medicine Freshers. Meandros I Med Dent Sci 2016; 17(3): 146.

15. Elders MJ, Perry CL, Eriksen MP, Giovino GA. The report of the surgeon general: preventing tobacco use among young people. Am J Public Health 1994; 84(4): 543-7.

16. Choi SH, Stommel M. Impact of age at smoking initiation on smoking-related morbidity and all-cause mortality. Am J Prev Med 2017; 53(1): 33-41.

17. Chinwong D, Mookmanee N, Chongpornchai J, Chinwong $S$. A comparison of gender differences in smoking behaviors, intention to quit, and nicotine dependence among Thai university students. I Addict 2018; 24; 2018: 8081670 .

18. Khang Y-H, Lynch J, Jung-Choi K, Cho H-J. Explaining agespecific inequalities in mortality from all causes, cardiovascular disease and ischaemic heart disease among South Korean male public servants: relative and absolute perspectives. Heart 2008; 94(1): 75-82.

19. Rani M, Bonu S, Jha P, Nguyen S, Jamjoum L. Tobacco use in India: prevalence and predictors of smoking and chewing in a national cross sectional household survey. Tob Control 2003; 12(4): e4.

20. Doku DT, Acacio-Claro PJ, Koivusilta L, Rimpelä A. Health and socioeconomic circumstances over three generations as predictors of youth unemployment trajectories. Eur J Public Health 2019; 29(3): 517-23.

21. Telli C, Aytemur Solak Z, Ozol D, Sayiner A. Smoking habits among newly registered university students. Eurasian I Pulmonol 2004; 6(3): 101-6.

22. Doğan D, Ulukol B. Factors contributing to smoking and efficiency of two different education models among adolescents. J Inonu Univ Med Fac 2010; 17(3): 179-85.

23. Pang RD, Bello MS, Liautaud $M M$, Weinberger $A H$, Leventhal AM. Gender differences in negative affect during acute tobacco abstinence differ between African American and White adult cigarette smokers. Nicotine Tob Res 2019; 21(8): 1072-8. 